UDK: $159.922 .72-053.2$

Izvorni naučni rad

Dr. sc. Fehim Rošić, vanredni profesor

Univerzitet u Bihaću

Pedagoški fakultet

fehim.rosic@gmail.com

\title{
PRAĆENJE RANOG RASTA I RAZVOJA PREDŠKOLSKOG DJETETA - KARAKTERISTIKE I NORME RAZVOJA
}

\section{Sažetak}

Period najranijeg razvoja ljudske jedinke je najintenzivniji i najdinamičniji razvojni period $i$ izuzetno je značajan u procesu ukupnog čovjekovog rasta $i$ razvoja. Razvoj u ovom periodu je, po mnogo karakteristika, drukčiji od razvoja u narednim periodima. Iako je proces razvoja jedinstven i integralan, on se može pratiti, proučavati i analizirati po zasebnim područjima, tjelesnog, kognitivnog, socio-emocionalnog ili jezičkog razvoja. Na osnovu ostvarenih naučnih saznanja utvrdene su odredene norme koje, kao orijentacioni pokazatelji, pomažu u praćenju toka ovog razvoja. Poznavanje osobenosti razvoja u predškolskoj dobi i njegovo praćenje ima poseban preventivni značaj sa stanovista pravovremenog prepoznavanja smetnji, zaostajanja ili poremećaja u razvoju, ali $i$ znaćaj za samu odgojnu praksu u smislu obezbjedivanja optimalnih uvjeta za rast $i$ razvoj djeteta.

Ključne riječi: razvoj, zakonitosti ranog razvoja, norme, LAP-norme, percentilne norme

\section{UVOD}

Razvoj u predškolskoj dobi je vrlo složen i dinamičan proces. Niti u jednom drugom vremenskom razdoblju života istog trajanja ljudsko biće ne doživi tolike promjene. Starosna razlika od godinu, pa i više, u zreloj dobi ne znači skoro ništa, ali mjesec dana u dojenačkoj, a par mjeseci ili jedna godina u predškolskoj dobi znače veliku razliku.

U ovoj dobi dijete se neprestano mijenja, ono svakodnevno stječe i pokazuje nešto novo, neke nove osobine i postupke. Potrebno je znati i moći prepoznati što je od toga, što dijete pokazuje u svom ponašanju, 
uobičajeno za tu dob, a što nije, da bismo mogli pratiti i procjenjivati njegov razvoj. Ako se u dječjem razvoju pojave poteškoće i odstupanja, djetetu se mora pružiti pomoć, jer ono samo, niti je u stanju ta odstupanja prepoznati, niti samo može pronaći efikasno rješenje. Osobenosti ranog psiho-socijalnog razvoja treba poznavati, jer jedino tada se može pomoći djetetu u prevladavanju razvojnih teškoća i poremećaja u njegovom razvoju, ali i efikasno i pravovremeno utjecati da do tih poremećaja ne dođe i da se oni ne razviju, dakle, možemo tek tada uspješno preventivno djelovati.

Svaka individua je tokom svog cjelokupnog života i funkcioniranja u stalnoj interakciji sa svojom okolinom. Taj proces je permanentan i obostran, a njegovi efekti i konsekvence javljaju se i kod individue $\mathrm{i}$ kod njene okoline. Efekti ovih interakcijskih odnosa mogu povoljno utjecati na razvoj individue, mogu poticati njen razvoj, pomoći njenoj integraciji i prilagodbi okolini, ali mogu imati i štetno djelovanje po razvoj, uspješnost funkcioniranja i psihički život individue. Ovo je posebno značajno u periodu kada individua stiče prva iskustva, kada uspostavlja svoje prve relacije sa okolinom i kada doživljava prve uspjehe ili neuspjehe kroz ove konfrontacije.

Razvoj djeteta je rezultat specifične sprege unutrašnjih i vanjskih faktora, što uvjetuje brojne posebnosti u odnosu na zrelu odraslu dob. Svaki simptom koji se kod djeteta manifestira i koji upućuje na određena odstupanja u razvoju, rezultat je nesklada između unutrašnje psihičke konstelacije djeteta i utjecaja vanjskih faktora.

\section{KARAKTERISTIKE RAZVOJA}

Razvoj svakog živog organizma ima svoje filogenetske karakteristike koje su svojstvene za tu vrstu, ali i ontogenetske karakteristike koje su svojstvene za razvoj same jedinke određene vrste. U živom svijetu poznata su tri oblika tog razvoja: linearni razvoj, razvoj kroz metamorfozu i skokoviti razvoj ili razvoj na mahove.

Linearni razvoj je karakterističan za biljke - kod drveta je razvoj linearan: jedan god za jednu godinu i starost drveta se određuje prema broju godova. Ti godovi nisu idealno koncentrični i nisu iste širine zbog uticaja brojnih vanjskih i unutrašnjih faktora; neke biljne vrste imaju posebno karakterističan tok razvoja. Tako kod kineskog bambusa kad 
se sjeme stavi u zemlju tek nakon tri godine iznad zemlje se pojavi jedan kržljav izdanak, a tokom četvrte godine bambus izraste u visinu preko 30 metara. (Pašalić Kreso, A. 2004.)

Razvoj kroz metamorfozu karakterističan je kod leptira i žaba. Kod leptira se iz jedne sive larve razvije gusjenica, a zatim leptir blistavih boja, a od punoglavca nastane žaba. Ovaj razvoj se dešava kroz iznenadne i velike promjene, tako da se jedva može vjerovati da se ovo kasnije razvilo iz onog prethodnog. (Hwang, P., Nilson, B. 2000.)

Skokovit razvoj ili razvoj na mahove je karakterističan za čovjeka. Taj razvoj nije linearan, niti prolazi kroz metamorfoze, on je kao penjanje uz stepenice: čovjek se jedno vrijeme nalazi na jednoj stepenici, a onda zakorači i dospije korak više. Svaki novi korak predstavlja iznenadnu i naglu promjenu jedinke i vodi je ka novim oblicima mišljenja, ponašanja i odnosa prema drugima.

Razvoj djeteta u predškolskoj dobi ima posebne karakteristike, koje ovaj period čine specifičnim i drukčijim u odnosu na dalji razvoj, a obuhvataju sljedeće

a) intenzitet - period najburnijeg rasta i razvoja (najbrži do treće godine, a u prvih šest godina trostruko je veći nego u slijedećih 12 godina)

b) dijete je aktivan činilac sopstvenog razvoja,

c) dječje učenje nije minijatura učenja odraslih - da bi dijete steklo svojih prvih pet aktivnih riječi potrebna mu je cijela prva godina, a u desetoj godini može za svega nekoliko minuta naučiti pet riječi nekog stranog jezika,

d) dječji razvoj se odvija u socijalnom kontekstu. Primjeri „,animalizirane djece“ koja su odrastala izvan društvenog konteksta, pokazuju da je razvoj nemoguć izvan uticaja društvenog konteksta.

\section{Primjer 1.}

Dvije djevojčice uzrasta 2 i 8 godina pronađene su $u$ vučjoj jami $u$ Indiji.Ponašale su se kao životinje: nisu znale govoriti, trčale su četvoronoške, hranu grizle zubima, oglašavale se samo neartikulisanim glasovima, bježale su od ljudi i najradije se družile sa psima.Mlađa djevojčica je umrla nakon jedne godine, a sa starijom se misionar, koji ih je pronašao trudio još punih 
devet godina i nije mogla naučiti govoriti.(prema: J.A.Singh: «Wolf Children and Feral Man», Harper and Brothers, London, 1930., preuzeto iz: Bergant M. 1974. str. 22.)

\section{Primjer 2.}

U Francuskoj, u blizini Aveyrona, 1798. godine lovci su u šumi pronašli 11godišnjeg dječaka, kojeg su mještani povremeno primjećivali u šumi tokom 7 godina.Kada je dječak uhvaćen, nije znao govoriti, odbijao je odjeću, posebno obuću, krevet i kuhanu hranu.Nije prihvatao kontakt sa ljudima, ugrizao bi svakog ko mu se približi. Brigu o njemu preuzeo je liječnik Itard, koji je vodio zavod za gluhonijemu djecu.Bio je uvjeren da je dječak samo odgojno zapušten, a da nije umno defektno dijete, inače se ne bi mogao tako dugo održati na životu u tako nepovoljnim uvjetima.Dječak je dugo vremena posebnim metodama obučavan čitanju i pisanju, ali je uspjeh bio djelimičan.( prema: J.A.Singh: «Wolf Children and Feral Man», Harper and Brothers, London, 1930., preuzeto iz: Bergant M. 1974. str. 22.-23.)

\section{Primjer 3.}

U Americi su pronađene dvije nezakonite djevojčice, koje su njihove majke, iz straha od osude društva, skrivale i držale zatvorene, brinući se jedva za njihove tjelesne potrebe, a njihov duševni razvoj su potpuno zanemarile.Prva djevojčica je pronađena kad joj je bilo 6 godina, bila je potpuno apatična, nepomično je ležala na leđima, prema svemu je bila potpuno indiferentna $i$ fizički je jedva nalikovala ljudskom biću.Živjela je još 4 godine u zavodu za defektnu djecu i pored velikih nastojanja u razvoju je ostala na stupnju razvoja devetogodišnjeg djeteta.Sudbina druge pronađene 6-godišnje nezakonite djevojčice je bila nešto bolja.Njena majka ju je naučila skromnom sporazumijevanju pomoću kretnji, ali nije pokazivala nikakve socijalne sposobnosti i reagirala je na ljude kao divlja životinjica.Iako su njena osjetila bila zdrava, pružala je sliku odgojno zapuštenog gluhonijemog djeteta: uz kretnje se oglašavala samo neartikuliranim glasovima.Nakon dugotrajnih početnih teškoća, uz intenzivan i stručan odgojni rad, napredovala je i razvila se gotovo do normalne mentalne dobi.Ispitivanja su pokazala da je raspolagala iznadprosječno visokim umnim dispozicijama.(prema: J.A.Singh: «Wolf Children and Feral Man», Harper and Brothers, London, 1930., preuzeto iz: Bergant M. 1974. str. 23.) 
e) nestabilnost dječje pažnje, koja je uslovljena dječjom potrebom za aktivnošću, a ako je iskorištena na odgovarajući način sadrži ogromne odgojno-obrazovne mogućnosti.

U razvoju djeteta predškolske dobi uočene su slijedeće zakonitosti po kojima se taj razvoj odvija:

a) intermitentnost - dječji razvoj, naročito u prvim godinama ne teče ravnomjerno, već ciklično: pojedini oblici ponašanja se pojave i gube, da bi se ponovo pojavili i gubili. Ovi intervali se sve više skraćuju, dok se na kraju taj oblik ponašanja ne ustali.

b) alternativnost-kada se jedna funkcija naglo razvija, druga stagnira: ima se utisak kao da beba planski savlađuje jednu vještinu, a ostale ostavlja po strani, kako bi kad onu prvu usavrši mogla preći na drugu. ( Čolanović-Smiljanić, V. 1968.)

c) konstantnost razvojnog reda - bez obzira što se jedna djeca razvijaju brže od drugih, razvojni red u pojavljivanju funkcija ostaje nepromijenjen (sjekutići niču prije kutnjaka, u crtanju dijete prvo crta krug, pa kvadrat, a zatim trokut, dijete zrenjem prvo može da sjedi, zatim da stoji, a tek poslije da hoda). Po Pijažeu ovo je najjači dokaz da se razvoj nalazi pod uticajem bioloških mehanizama, zavisnih od sazrijevanja. (Ross, V., Marshall, M. H., Scott, A. M. 1998.).

d) cefalo-kaudalni pravac pravac razvoja - fizički, motorni i senzorni razvoj se odvija od glave prema donjim ekstremitetima. U prenatalnom razvoju prvo se uobličava glava; po rođenju dijete prvo savlađuje zemljinu težu podizanjem glave, taktilna osjetljivost prvo je javlja u predjelu usta i nosa.

e) proksimo-distalni pravac razvoja - motorni i senzorni razvoj se odvija od kičmene moždine ka dijelovima tijela udaljenijim od nje: mišići šake, pošto su udaljeniji od i kičme, razvijaju se sporije i kasnije od mišića nadlaktice.

f) razvoj od podjednake kontrole bilateralnih $\mathrm{ka}$ boljoj kontroli unilateralnih organa-anatomski, fiziološki i funkcionalno dijete je po rođenju simetrično, a razvojem postaje asimetrično ili unilateralno. Sinistrizam ili dekstrizam, kao dominacija lijeve ili 
desne simetrične strane tijela javlja se i u području motorike, ali i u području vida i sluha.

g) tendencija eliminisanja suvišnog angažovanja mišića-djeca u obavljanju neke radnje u početku angažiraju znatno više mišića nego što je to potrebno, a kasnije se postepeno odbacuje angažiranje nepotrebnih mišića za neku aktivnost.

Ove zakonitosti ili pravilnosti psihološkog razvoja u ranom djetinjstvu treba poznavati da bi se prepoznale smetnje ili odstupanja u tom razvoju. Međutim, one se ne smiju kruto prihvatiti, jer proces biološkog sazrijevanja djeteta ranog uzrasta je vrlo intenzivan i njegov nervni sistem i psihičke funkcije pokazuju veliku plastičnost, odnosno, podložnost utjecajima okoline u kojoj dijete odrasta, a koji su tada posebno snažni i ostavljaju trajne posljedice. Dijete je prijemčivo za sve utiske koji dolaze iz njegove okoline i prvih nekoliko godina dijete nauči više nego u bilo kojem drugom periodu njegovog življenja.

$\mathrm{Za}$ razliku od čovjeka, životinji je već rođenjem namijenjeno da instinktivno živi i djeluje. Međutim, čovjek svojim rođenjem je određen za život u društvu i učenje u djetinjstvu. Bez tog učenja, nemoguć je njegov razvoj, pa i dalji život. To učenje u djetinjstvu je toliko važno, da ga neki antropolozi i psiholozi nazivaju drugim djetetovim rođenjem.

\section{NORMIRANJE I PRAĆENJE RANOG RAZVOJA}

Naučni pristupi u proučavanju, objašnjenju i interpretaciji čovjekovog razvoja različiti su kod pojedinih psiholoških teorija i pravaca. U tim pristupima, kada je u pitanju periodizacija tog razvoja, navode se periodi kriza u razvoju, a prema nekim autorima je cijelo predškolsko doba kritični period u razvoju (Kamenov E., prema Mitrović D., 2002.), dok drugi autori razlikuju manje ili više posebnih kriznih etapa ili razvojnih kriza. Prema psihoanalitičkoj teoriji, čiji je utemeljitelj i osnivač Sigmund Freud, ljudski se razvoj odvija u pet faza:

a) Oralna faza (od rođenja do otprilike 18 mieseci): U ovoj fazi glavni izvor tjelesnog užitka djeteta vezan je za usta. Freud je smatrao da najsnažniji dugoročni utjecaj u ovoj fazi ima to kada je i koliko dijete dojeno i kako je navikavano na drugu hranu. 
b) Analna faza (od 18 mjeseci do 3 godine): Dijete u ovoj fazi postiže osjećaj zadovoljstva, prvo puštajući rad crijeva, a zatim kočeći i suzdržavajući se od te aktivnosti. Najvažnije utjecaje u ovoj fazi imaju iskustva koja dijete stječe prilikom uvježbavanja higijenskih navika.

c) Falusna faza(od 3. do 5. godine): Dijete postiže užitak i ugodu neposrednim podraživanjem svojih spolnih organa. U ovoj fazi, po Freudu, dijete prolazi kroz posebnu konfliktnu situaciju, tzv., Edipski kompleks, koji predstavlja «organizirani sklop ljubavnih i neprijateljskih želja što ih dijete osjeća spram roditelja» (Laplanche, J., Pontalis, J. B., 1992. str 63.). Tada se na stanovit način prvi put u djetetovom spoznajnom svijetu pojavljuje otac, što potpomaže djetetovo odvajanje od majke, čime ono postupno iz faze dijade (dijete - majka) prelazi u fazu triangulacije, i kod djeteta se postupno formira svijest o porodičnom nukleusu ili primarnoj obitelji. Kako će dijete proraditi i razriješiti ovaj konflikt, koji za njega predstavlja vrlo snažnu krizu, značajno je za njegov kasniji psihički razvoj. Prema psihoanalitičkom gledištu, velik broj ozbiljnih duševnih teškoća i poremećaja svoje uzroke upravo imaju u ovim ranim fazama dječijeg razvoja, a posebno u falusnoj fazi vezano za Edipsku dramu i prvu triangulaciju.

d) Faza latencije(od 6. do 12. godine): Libidonozni nagoni, želje i interesovanja su potisnuta i neaktivna.

e) Genitalna faza (od 12. godine nadalje): Kod djeteta se ponovo javlja interes i sklonost prema suprotnom spolu, ali sada prema osobama suprotnog spola istog ili bliskog uzrasta.

Psihoanaliza polazi od toga da su mnogi aspekti ličnosti odrasle osobe rezultat pregenitalnog razvoja $\mathrm{u}$ ranom djetinjstvu. Ako dijete npr., u prvoj fazi nije imalo prikladnu količinu oralnog zadovoljstva, u kasnijim razvojnim i životnim fazama će pojačano tražiti ugodu u ovoj erogenoj zoni, što se može manifestirati kroz jaču sklonost ka nastajanju i učvršćivanju navika vezanih za usta (pušenje, žvakanje i griženje olovke, grickanje noktiju, neuobičajeno zanimanje za ljubljenje i dr.)

Eriksonova (Erik Homburger Erikson) psihosocijalna teorija na razvoj gleda kao na proces koji traje tokom cijeloga života. U tom procesu, 
ljudska jedinka prolazi kroz osam faza ili kriza, u kojima ima mogućnost da postigne dobre ili loše ishode, odnosno, rješenja konflikta.

Od navedenih osam razvojnih kriza ili faza, prve tri obuhvataju period razvoja predškolskog djeteta. U prvoj fazi dijete može doživjeti konflikt na relaciji povjerenje - nepovjerenje ovisno o tome koliko i kako druge osobe zadovoljavaju njegove osnovne životne potrebe (potrebe za hranom, toplinom, zaštitom, bliskošću, kontaktom i dr.) Ako su odgovori drugih osoba na ove potrebe djeteta pozitivni, to će kod djeteta jačati osjećaj sigurnosti, poticati razvoj povjerenja u sebe i okolinu, razvoj frustracione tolerantnosti, spremnost da odgodi zadovoljenje potreba, dijete će sticati iskustva da od drugih može dobivati, ali da treba i drugima davati i sl. Ako dijete u reakcijama drugih osoba ne prepoznaje zadovoljenje svojih potreba, ishod iz ove krize rezultirat će negativnim posljedicama.

Osnovni elementi tih razvojnih kriza mogu se prikazati na sljedeći način: 
Tabela 1: Razvojne krize po Eriksonu (prema Hwang P., Nilson B. 2000. str. 45.)

\begin{tabular}{|c|c|c|c|}
\hline 苛 & $\begin{array}{l}\text { GLAVNI } \\
\text { KONFLIKT }\end{array}$ & $\begin{array}{l}\text { POZITIVNI } \\
\text { REZULTAT }\end{array}$ & $\begin{array}{l}\text { NEGATIVNI } \\
\text { REZULTAT }\end{array}$ \\
\hline $0-1,5$ & $\begin{array}{l}\text { Povjerenje - } \\
\text { nepovjerenje }\end{array}$ & $\begin{array}{l}\text { Nada, prebrođuje } \\
\text { frustraciju, može } \\
\text { odgoditi zadovoljenje } \\
\text { potreba }\end{array}$ & $\begin{array}{l}\text { Sumnjičavost, } \\
\text { obeshrabrenost, } \\
\text { rezignacija, povučenost }\end{array}$ \\
\hline $1,5-3$ & $\begin{array}{l}\text { Autonomija- } \\
\text { sumnja }\end{array}$ & $\begin{array}{l}\text { Volja, samokontrola, } \\
\text { pozitivna samosvijest }\end{array}$ & $\begin{array}{l}\text { Prisilne radnje, loša } \\
\text { impulsna kontrola }\end{array}$ \\
\hline $3-6$ & $\begin{array}{l}\text { Inicijativa - } \\
\text { krivnja }\end{array}$ & $\begin{array}{l}\text { Radost uspjeha, } \\
\text { radoznalost }\end{array}$ & $\begin{array}{l}\text { Sputavanje, nedostatak } \\
\text { inicijative, pasivnost }\end{array}$ \\
\hline $6-12$ & $\begin{array}{l}\text { Aktivnost - } \\
\text { inferiornost }\end{array}$ & $\begin{array}{l}\text { Kompetentnost, } \\
\text { dostatnost kao čovjeka }\end{array}$ & Nedovoljnost \\
\hline $12-20$ & $\begin{array}{l}\text { Identitet - } \\
\text { pometnja } \\
\text { uloga }\end{array}$ & $\begin{array}{l}\text { Integrirana slika sebe, } \\
\text { vjera u budućnost }\end{array}$ & $\begin{array}{l}\text { Disharmonična slika } \\
\text { sebe, prkos, negativni } \\
\text { identitet, pretjerano } \\
\text { prilagođavanje, } \\
\text { depresija }\end{array}$ \\
\hline $20-40$ & $\begin{array}{l}\text { Bliskost - } \\
\text { izoliranje }\end{array}$ & Ljubav, bliskost & $\begin{array}{l}\text { Poricanje, strah od } \\
\text { bliskosti }\end{array}$ \\
\hline $40-60$ & $\begin{array}{l}\text { Produktivnost- } \\
\text { stagnacija }\end{array}$ & $\begin{array}{l}\text { Skrb, odgovornost za } \\
\text { dolazeće generacije }\end{array}$ & Poricanje, samovoljnost \\
\hline $60-$ & $\begin{array}{ll}\text { Integritet - } & \\
& \text { očaj }\end{array}$ & Mudrost & $\begin{array}{l}\text { Gnušanje, prezir, } \\
\text { beznadežnost }\end{array}$ \\
\hline
\end{tabular}

U drugoj razvojnoj krizi djeca imaju potrebu za samostalnošću, potrebu da budu autonomna u svojim svakodnevnim aktivnostima. Ako druge osobe pozitivno reagiraju na ove potrebe, dijete razvija i učvršćuje povjerenje u svoje sposobnosti i time jača samopouzdanje. Ono tada postaje sposobnije da kontrolira svoje postupke i da razvija realnu sliku i svijest o sebi. Sumnja u svoje sposobnosti, koja se kod djeteta javlja ako odrasle osobe ne prepoznaju njegovu potrebu za samostalnošću, može se manifestirati kroz pojave prisilnog ponavljanja elemenata $u$ djetetovom ponašanju, kroz pretjeranu ovisnost, oslabljenu volju i kroz teškoće u razlikovanju svojih i tuđih potreba. 
U uzrasnoj dobi 3-6 godina dijete, po Eriksonu, prolazi kroz krizu označenu kao inicijativa nasuprot krivnji, koja se ogleda u sukobu između dječije potrebe da participira u predlaganju i pronalaženju rješenja i donošenju odluka, s jedne strane, $\mathrm{i}$ eventualnog neprihvatanja i neprepoznavanja te potrebe od strane drugih osoba, s druge strane, što god djeteta stvara osjećaj da time griješi da se, zbog toga, osjeti krivim. Ako se inicijative djeteta podrže, prihvate i dijete dobije potvrdu njihove ispravnosti, to će kod djeteta izazvati radost uspjeha, radoznalost i usklađenost uloga.U protivnom, dijete će pokazivati sputanost, stvoriti sliku o sebi kao nedostatnoj osobi i razvijati osjećaj vlastite krivnje zbog toga.

\subsection{Kognitivni razvoj}

U trenutku kada čovjek, kao biće, započinje svoj život on, zapravo ne zna ništa o svijetu koji ga okružuje i da bi u tom svijetu opstao, on je prinuđen da se razvija i da uči. Za taj proces, koji je zapravo presudan za njegov opstanak, on rođenjem donosi na svijet samo predispozicije, koje čine osnovu za razvoj i učenje i koje mogu, ali i ne moraju biti iskorištene.

Po teoriji koju je razvio Jean Piaget, kao predstavnik kognitivne razvojne psihologije, prva od četiri faze ili stadija kroz koje čovjek prolazi u svom razmišljanju i tumačenju svijeta koji ga okružuje je senzo-motorička faza koja obuhvata prve dvije godine života i u kojoj se može razlikovati šest razvojnih etapa sa slijedećim karakterističnim obilježjima u ponašanju:

a) U prvoj etapi djetetovim ponašanjem dominiraju urođeni refleksi (Babinskijev, Morov, Babkinov, palmarni refleks i dr.)

b) Druga etapa je karakteristična po cirkularnim reakcijama, koje se u ponašanju manifestiraju kroz ponavljanja (npr., primarne cirkularne reakcije koje se tiču djetetovoga vlastitog tijela)

c) U trećoj fazi se uočava namjera i usmjerenost djetetove aktivnosti prema cilju, što predstavlja početak postojanosti objekta (karakteristična za uzrasnu dob 4-8 mjeseci)

d) Na uzrastu 8-12 mjeseci usmjerenje djetetove aktivnosti prema cilju je vidljivije izraženo, dijete npr., traži skrivene predmete. 
e) Petu etapu karakteriziraju tercijarne cirkularne reakcije, koje se manifestiraju u ponavljanju aktivnosti, što upućuje na relaciju povod - efekat i predstavlja izvjesno shvaćanje kauzalnosti.

f) U posljednjoj, šestoj, etapi senzo-motoričke faze razvoja javljaju se počeci formiranja pojma uzroka, reprezentacija predmeta i stvaranje predodžbe o svijetu oko sebe

Kognitivni razvoj, nakon senzo-motoričke faze po Piagetovoj teoriji, prolazi kroz fazu preoperacionalnog mišljenja, koja obuhvaća period između 2 i 7 godina. Ova faza prethodi operacionalnom mišljenju, a koje je, zapravo neophodno da bi se dijete moglo osloboditi egocentrizma. Osnovne karakteristike preoperacionalne faze kognitivnog razvoja su:

a) Nereverzibilnost: Dijete u misaonom rasuđivanju još ne može primijeniti inverzni put. Ono npr., može razumjeti da 3 i 4 zajedno daju 7, ali će teško pronaći misaonim putem rješenje za problem: koliko nam ostaje ako od 7 oduzmemo 4.

b) Centriranje: Ova karakteristika preoperacionalnog mišljenja se manifestira u sklonosti djeteta ove uzrasne dobi da se usmjeri samo na jedan aspekt problema u određenom trenutku, što često dovodi do netačnog prosuđivanja.

c) Konzervacija: Ova karakteristika kognitivnog razvoja djeteta u preoperacionalnoj fazi razvoja odnosi se na dječje poimanje konstantnosti jedne veličine prilikom mijenjanja drugih svojstava koja ne utječu na tu veličinu.Ako, npr., jednu količinu tečnosti iz providne široke posude prespemo u providnu usku, a visoku posudu, gotovo sva djeca mlađa od 5 ili 6 godina će odgovoriti da se u uskoj posudi nalazi veća količina tečnosti, dok skoro nijedno dijete od 8 godina to neće reći. Djeca u preoperacionalnoj fazi ne mogu shvatiti da stvarnost ostaje ista, uprkos tome što je čovjek doživljava na različite načine.

d) Egocentrizam: Egocentrizam ne znači egoizam, već se odnosi na činjenicu da dijete u preoperacijskoj fazi ima ograničenu sposobnost predočavanja psihičkog iskustva drugih osoba. Ono se ponaša kao da svi drugi dijele njegov pogled na svijet $i$ vide ono što i ono vidi, osjećaju ono što ono osjeća ili znaju ono što ono zna. 
Za dječije doživljavanje stvarnosti u predškolskoj dobi, njegovo mišljenje i rasuđivanje, karakteristična su još dva fenomena ili osobenosti: animizam i artificijalizam.

Animizam se manifestira na način da dijete pripisuje predmetima atribute živog bića: predmeti su za malo dijete živi, imaju misli i osjećaje kao ljudi, njih je neko rodio, oni imaju interese i potrebe kao i živi ljudi i sl. Dijete ovog uzrasta, ne samo da predmetima pripisuje ova svojstva, nego ono predmete uistinu takvima vidi i doživljava u svom svijetu.

Artificijalizam označava karakteristiku mišljenja, opažanja i doživljavanja djeteta ove dobi, koja se manifestira kroz dječije poimanje da su različite objekte proizveli odrasli ljudi na isti način: mlijeko se napravi kao sok, samo je bijelo, oblake su napravili ljudi od pamuka, perja ili papira i sl.

Na temelju brojnih empirijskih istraživanja i teorijskih analiza, došlo se do određenih razvojnih ljestvica ili normi koje pokazuju koji su manifestni oblici kognitivnog ponašanja karakteristični za svaki pojedini vremenski interval $u$ toku jedne razvojne faze. Ove razvojne ljestvice pomažu, uz uvažavanje specifičnosti i individualnih razlika, u procjeni normalnosti toka razvoja, odnosno, eventualnog zaostajanja ili odstupanja. Između mnogih, jedno uspješno rješenje za praktično praćenje kognitivnog razvoja djeteta u razdoblju 12-72 mjeseca, omogućuje LAP-ljestvica (Learning Accomplishment Profile - Profil napredovanja u učenju, Chapel Hill Training Outreach Project, 1998.):

Tabela 2: Kognitivni razvoj djeteta (prema Learning Accomplishment Profil -LAP)

\begin{tabular}{|c|c|}
\hline 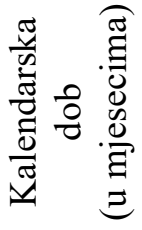 & Kognitivne operacije koje dijete uspješno obavlja \\
\hline 12 & Otvara poklopac kutije da nađe igračku \\
\hline 16 & Vadi predmete iz boce \\
\hline 17 & Dohvata igračku štapom \\
\hline 24 & \begin{tabular}{|l|l} 
Vuče prostirač da dohvati objekat & Daje objekte slične uzorku \\
\end{tabular} \\
\hline 27 & Ponavlja dva broja od 1 do 9 \\
\hline
\end{tabular}




\begin{tabular}{|c|c|c|}
\hline 30 & \multicolumn{2}{|l|}{ Daje jedan objekat } \\
\hline 36 & $\begin{array}{l}\text { Sortira kocke u dvije } \\
\text { različite boje } \\
\text { Ponavlja tri broja od } 1 \text { do } \\
\text { 9. Broji do } 3 \text {. } \\
\text { Daje dva objekta }\end{array}$ & $\begin{array}{l}\text { Pokazuje na velike } \\
\text { objekte.Pokazuje na male objekt. } \\
\text { Daje jedne i druge objekte. } \\
\text { Pokazuje na različite objekte }\end{array}$ \\
\hline 42 & $\begin{array}{l}\text { Pokazuje neprazne } \\
\text { objekte. Prepoznaje dvije } \\
\text { boje. Broji tri objekta. } \\
\text { Pokazuje mali kvadrat. } \\
\text { Postavlja prstenove po } \\
\text { veličini }\end{array}$ & $\begin{array}{l}\text { Pokazuje na druge objekte. } \\
\text { Imenuje poznatu melodiju. } \\
\text { Svrstava slike pokazujući } \\
\text { Povezuje set kocaka }\end{array}$ \\
\hline 48 & $\begin{array}{l}\text { Prepoznaje } 4 \text { boje. Daje } \\
\text { teške predmete. Pokazuje } \\
\text { na grube i nježne teksture. } \\
\text { Eliminira verbalne } \\
\text { nelogičnosti }\end{array}$ & $\begin{array}{l}\text { Povezuje slike visokih predmeta. } \\
\text { Prepoznaje povezane slike. Broji } \\
\text { mehanički do } 10 \text {. } \\
\text { Imenuje objekte koji nedostaju }\end{array}$ \\
\hline 54 & $\begin{array}{l}\text { Ponavlja } 4 \text { broja. } \\
\text { Razaznaje metalne } \\
\text { novčanice. Pokazuje tvrde } \\
\text { i mekane teksture. Daje tri } \\
\text { objekta. Pokazuje slike } \\
\text { dana i noći }\end{array}$ & $\begin{array}{l}\text { Pokazuje na krug. Broji četiri } \\
\text { predmeta } \\
\text { Pokazuje } 4 \text { boje. Pokazuje na } \\
\text { trokut } \\
\text { Broji mehanički do } 15\end{array}$ \\
\hline 60 & $\begin{array}{l}\text { Imitira oblik vijka. } \\
\text { Pokazuje na skup sa više } \\
\text { dijelova. Pokazuje na sliku } \\
\text { koja je prva u redu. } \\
\text { Imenuje tri novčića. Reda } \\
\text { brojeve od } 1 \text { do } 10 . \\
\text { Pokazuje na skup sa manje } \\
\text { dijelova } \\
\text { Pokazuje kvadrat }\end{array}$ & $\begin{array}{l}\text { Imenuje brojeve od } 1 \text { do } 3 \\
\text { Imenuje } 4 \text { boje } \\
\text { Pokazuje pravougaonik } \\
\text { Broji } 10 \text { predmeta } \\
\text { Pokazuje } 8 \text { boja } \\
\text { Imenuje i kaže kako se koristi sat }\end{array}$ \\
\hline 66 & $\begin{array}{l}\text { Pokazuje papirnu } \\
\text { novčanicu } \\
\text { Pokazuje na sliku } \\
\text { posljednju u redu } \\
\text { Kaže koliko ima manjih } \\
\text { novčanica u većoj. } \\
\text { Pokazuje na srednji } \\
\text { predmet u grupi. Broji } \\
\text { mehanički do } 20\end{array}$ & $\begin{array}{l}\text { Opisuje vrijeme } \\
\text { Imenuje brojeve od } 1 \text { do } 9 \\
\text { Prepoznaje veću papirnu } \\
\text { novčanicu } \\
\text { Kaže broj polovina u cijelom } \\
\text { Broji } 13 \text { predmeta } \\
\text { Kaže brojeve koji su iza } 8,3,6,9 \\
\text { Imenuje i objašnjava korištenje } \\
\text { kalendara }\end{array}$ \\
\hline
\end{tabular}




\begin{tabular}{|c|c|c|}
\hline & $\begin{array}{l}\text { Verbalizuje razumijevanje } \\
\text { pojma veći } \\
\text { Reda oblike po veličini }\end{array}$ & \\
\hline 72 & $\begin{array}{l}\text { Svrstava grupe slika od } 1 \\
\text { do } 3 \text { sa brojevima. } \\
\text { Verbalizuje razumijevanje } \\
\text { pojmova: jutro, popodne. } \\
\text { Imenuje } 4 \text { novčića. Bira } \\
\text { napisani telefonski broj } \\
\text { Broji mehanički do } 30 \\
\text { Reda brojeve od } 1 \text { do } 5 \text { u } \\
\text { niz } \\
\text { Broji } 20 \text { predmeta } \\
\text { Gradi tri stepenice od } \\
\text { kocaka (model od } 4 \\
\text { stepenice) } \\
\text { Daje } 6,7,8,10 \text { predmeta }\end{array}$ & $\begin{array}{l}\text { Imenuje brojeve od } 1 \text { do } 9 \\
\text { Kaže vrijeme u satima } \\
\text { Kaže broj sitnih novčanica u } \\
\text { većoj } \\
\text { Reda priču u slikama u nizu } \\
\text { Kaže sličnosti i razlike } \\
\text { Kaže broj prstiju na svakoj ruci i } \\
\text { na obje } \\
\text { Dodaje broj } 5 \\
\text { Oduzima broj } 5 \\
\text { Imenuje dane u sedmici } \\
\text { Nabraja } 30 \text { slova }\end{array}$ \\
\hline
\end{tabular}

Posebno značajan segment kognitivnog razvoja predškolskog djeteta predstavlja jezički razvoj. Značaj razvoja govora kod djeteta ogleda se, u prvom redu, u njegovoj vrlo kompleksnoj povezanosti sa mišljenjem: kroz govor se manifestira dječije mišljenje, poimanje sebe i stvarnosti, ali govor, istovremeno, utječe na dalji tok ukupnog kognitivnog razvoja kod djeteta. S druge strane, govor značajno utječe i na emocionalni, a posebno na socijalni razvoj djeteta: ono govorom iskazuje svoje doživljaje i osjećanja, doznaje o doživljajima drugih, govor mu omogućuje komunikaciju sa drugima u interakcijskim odnosima i tako izravno služi djetetovoj socijalizaciji.

Jezički razvoj u predškolskoj dobi je vrlo intenzivan i prolazi kroz više karakterističnih razvojnih etapa. U prvom, predverbalnom razdoblju, razdoblju koje prethodi izgovaranju prve riječi, uočljive su sljedeće osobenosti i momenti:

a) Gukanje: Na uzrastu već oko 2 mjeseca djeca počnu proizvoditi jednosložne vokalne zvukove, prvo samo sa jednim samoglasnikom (-a, -u, -o), a zatim u kombinaciji sa suglasnikom (-gu). Za razliku od ranijeg neartikuliranog oglašavanja, koje je obično upućivalo na neko stanje neugode kod djeteta, gukanje je praćeno sa smješkanjem ili smijanjem i predstavlja prvi prateći signal pozitivnih emocija. 
b) Slogovanje: U dobi oko 6 mjeseci dijete počinje da spaja nekoliko jednakih slogova (npr., ba-ba-ba), a kasnije im dodaje nove glasove. Približavanjem kraju prve godine, uočava se postepeno gubljenje ponavljanja kod slogovanja: dijete počinje kombinirati različite slogove, npr., da-du, ili bu-ba i sl. što predstavlja prve začetke obilježja govora Brojna ispitivanja (Oller i Eilers, 1988., Locke i Pearson, 1990., prema Vasta R. et al., 1998. str. 412-413.) kod gluhe djece i djece kod koje je slogovanje bilo spriječeno, ukazala su na presudan značaj slušanja vlastitog govora u daljem jezičkom razvoju djeteta.

c) Geste i neverbalne reakcije: Geste udružene sa drugim neverbalnim reakcijama javljaju se u predverbalnom razdoblju, ali su i dalje prisutne u verbalnoj fazi, za razliku od gukanja i slogovanja koje predstavljaju prolazne pojave u razvoju govora. U dobi od oko 8 ili 10 mjeseci djeca počinju koristiti gestovne reakcije i to uglavnom $u$ komunikaciji s majkom, sa ciljem da prenesu kroz takvu komunikaciju svoje zahtjeve. Ako dijete želi da mu mama doda igračku ili otvori kutiju, ono može signalizirati tu želju majci različitim neverbalnim reakcijama: naizmjenično gledanje u majku i taj predmet, pokreti ruku, micanje glavom i dr. Druga funkcija ranih gesta je tzv. referencijalna komunikacija, koja se javlja u dobi 11 ili 12 mjeseci, kojom dijete saopćava o nečemu u okolini. Ova gesta $u$ početku uključuje samo pokazivanje (prinosi predmet odraslom da bi mu ukazalo na njega), a kasnije se razvija u davanje. Bitno je davanje odgovora na ove reakcije, od osobe kojoj ih dijete upućuje, da bi se one dalje nastavile kao nužan oblik u razvoju govora.

Pojavom prve riječi, najčešće krajem prve godine, a kod većine djece u dobi 10-14 mjeseci, završava predverbalno razdoblje i počinje verbalna faza u razvoju govora.Jezički razvoj u predškolskoj dobi karakteriše sljedeće (prema Hwang P., Nilsson B., 2000. str. 167.): 
Tabela 3: Jezički razvoj djeteta (prema Hwang P., Nilsson B. 2000. str. 167.)

\begin{tabular}{|c|c|}
\hline $\begin{array}{c}\text { Dob } \\
\text { (u mjesecima) }\end{array}$ & Jezički razvoj \\
\hline $2-12$ & $\begin{array}{c}\text { Samoglasnici i suglasnici } \\
\text { Gukanje (samoglasnici suglasnici) }\end{array}$ \\
\hline $10-14$ & Prva riječ \\
\hline 18 & $\begin{array}{l}\text { Rečenice sastavljene od jedne riječi } \\
\text { Upotrebljava desetak riječi }\end{array}$ \\
\hline 24 & $\begin{array}{c}\text { Rečenice sastavljene od dvije riječi } \\
\text { «Što je to» - pitanja } \\
\text { Pretjerano generaliziranje } \\
\text { Fond riječi obuhvata oko } 300 \text { riječi }\end{array}$ \\
\hline 30 & $\begin{array}{c}\text { Telegramski jezik } \\
\text { Prosječna dužina rečenice oko } 4 \text { riječi }\end{array}$ \\
\hline 36 & $\begin{array}{l}\text { Rečenice sastavljene od više riječi } \\
\text { Lične zamjenice } \\
\text { Fond riječi se stalno povećava }\end{array}$ \\
\hline 42 & $\begin{array}{c}\text { Pravila slaganja (vremena, imenica) } \\
\text { Počinju prilagođavati upotrebu jezika prema } \\
\text { sugovorniku }\end{array}$ \\
\hline 48 & Veznici i prijedlozi \\
\hline 60 & Osnove gramatike \\
\hline 72 & Fond riječi obuhvata oko 15.000 riječi \\
\hline
\end{tabular}

\subsection{Socio-emocionalni razvoj}

Svojim rođenjem čovjek nije ni socijalno ni asocijalno ljudsko biće. On se rađa bez ikakvih navika ili znanja o ophođenju sa drugim ljudima, bez sposobnosti govora i komunikacije, bez kulture i morala, sa impulsima i nagonima koji čak otežavaju socijalni život. U stalnoj interakciji sa socijalnom sredinom, u kojoj čovjek živi, permanentno se odvija proces učenja oblika i načina ponašanja i reagiranja, čime pojedinac treba da postane socijalno razvijena i zrela ličnost. Taj proces socijalnog razvoja pojedinca tijesno je vezan sa procesom zrenja i teče uporedo sa kognitivnim razvojem. Međutim, da li će se dijete uspješno ili neuspješno prilagoditi životu, zavisi i od njegovog doživljavanja iskustava kroz koja prolazi. Emocije imaju vrlo velik, pa čak i prvorazredan značaj u životu djeteta, jer su neodvojivo povezane sa svim aspektima njegovoga razvoja. 
U ranom emocionalnom razvoju uočava se stanovita pravilnost i ravnomjernost promjena u nastajanju i ispoljavanju dječijih osjećanja. Prvi oblik emocionalnog ponašanja, neposredno po rođenju, predstavlja stanje opće uzbuđenosti novorođenčeta na neku stimulaciju, koje se poslije diferencira na ispoljavanje zadovoljstva ili nezadovoljstva. U dobi od 3 do 6 mjeseci, iz ranije difuznog stanja nezadovoljstva diferenciraju se redosljedom slijedeće emocije: gnjev, gađenje i strah, a iz stanja zadovoljstva, u dobi od 6-12 mjeseci: oduševljenje i privrženost odraslima, dok se tek poslije 12 mjeseci iz ovog stanja zadovoljstva razvija privrženost djeci.

Dječje ispoljavanje emocionalnih doživljaja je specifično u odnosu na odrasle. Na karakter i oblik tog ispoljavanja kod djeteta djeluje velik broj faktora, a poseban značaj imaju osobenosti socijalne komunikacije i dječje potrebe. Naime, za razliku od životinje, čovjekovo izražavanje potreba uvijek prate emocionalne reakcije.Tako, npr., prvi socijalni osmijeh javlja se već u dobi oko 6 sedmica, da bi na uzrastu poslije tri mjeseca postajao širi i postepeno prelazio u smijeh. Prema nalazima koje iznosi Desmond Morris (prema Hwang P., Nilsson B., 2000. str. 125.) ova emocionalna reakcija novorođenčeta je način iskazivanja njegove socijalne potrebe da odrasli ostanu u njegovoj blizini i da ga zaštite, jer, kako navodi autor, majmuni se ne osmjehuju pošto njihova mladunčad držeći se za majku i njeno krzno dobijaju sigurno uporište.Novorođenče nije u ovakvoj prilici, pa je njegov osmijeh pogodan način da se privole odrasli da ostanu u njegovoj blizini. Emocionalni razvoj djeteta se ne manifestira samo kroz oblike ispoljavanja njegovih osjećanja, već dijete tokom tog razvoja uči i stječe sposobnosti i da daje i da prima, odnosno, ono uči da iskaže svoja osjećanja, ali isto tako i da razumije i doživljava osjećanja drugih.Osim toga, dostižući emocionalnu zrelost, dijete nauči da kontrolira svoja osjećanja.Sposobnost emocionalne kontroleje, zapravo, jedan od ključnih kriterija emocionalne zrelosti.

Dječji emocionalni život i njegov razvoj u ranom djetinjstvu odlikuju brojne karakteristike, koje ga čine specifičnim i vrlo značajnim procesom za ukupni dječji razvoj i razvoj ličnosti.Te osobenosti se naročito ogledaju u slijedećem: 
a) Kratkoća emocija: Dijete izražava svoja osjećanja kroz reakcije koje kratko traju, a zatim naglo prestaju.Te reakcije su kratkotrajne, a intenzivne.

b) Intenzitet emocija: Dijete emocionalno reagira skoro istim intenzitetom na obične situacije kao i na vrlo delikatne i ozbiljne situacije.U emocionalnim reakcijama djeteta ne može se uočiti gradacija intenziteta.

c) Prolaznost emocija: Nakon jedne emocionalne reakcije dijete može za vrlo kratko vrijeme emocionalno reagirati potpuno drugom, često i suprotnom, emocijom: tek što je prestalo da plače, dijete može, skoro odmah, da se intenzivno smije.

d) Učestalost emocija: Prilagođavajući se različitim situacijama kod djeteta se uočava mnogo češća izmjena emocionalnih stanja nego kod odraslih osoba.Dijete odmah reagira na svaki doživljaj, pa je mijenjanje njegovog raspoloženja vrlo učestalo.

e) Individualne različitosti: Djeca istog uzrasta često reagiraju različito na iste situacije i podražaje.Što jedno dijete može zasmijati, drugo dijete može istovremeno uplašiti, a kod trećeg izazvati bijes, ljutnju, srdžbu ili ga rastužiti da plače.

f) Otvorenost ispoljavanja: Osjećanja kod djece se pouzdano mogu utvrditi na osnovu simptoma i reakcija koje pokazuju. Djeca otvoreno ispoljavaju ono što osjećaju, ona nisu u stanju prikrivati svoja osjećanja.

g) Promjenljivost intenziteta: Djeca različitog uzrasta, ali i ona iste uzrasne dobi, često na iste podražaje emocionalno reagiraju različitim intenzitetom: ako neki podražaj izaziva radost kod djece, neće se svako dijete jednako obradovati.

h) Razvojna postupnost $u$ ovladavanju emocijama: Uporedo sa procesom zrenja i emocionalnog razvoja teče i progresivan postupan razvoj djetetove sposobnosti da kontrolira svoje emocionalne reakcije.

i) Emocionalna osjetljivost: Predškolsko dijete snažno doživljava i intenzivno se uživljava u osjećanja drugih bliskih i dragih osoba.Ono je emocionalno hipersenzibilno, pa odrasli često, zanemarujući ovu činjenicu, ne mogu ili ne žele da razumiju da 
dijete može biti toliko tužno zbog nečeg što za odrasle predstavlja beznačajan razlog.

j) Specifičnost emocionalnih potreba djeteta: Dijete ima naglašeno snažnu potrebu da voli i da bude voljeno. Ako odrasli ne uvaže i ne prepoznaju ovu potrebu, odnosno, ako na nju ne odgovaraju adekvatno, to će se vrlo štetno odraziti na emocionalni razvoj djeteta i na razvoj njegove ličnosti.

Predškolsko dijete u toku svog socijalnog razvoja pokazuje jedan broj karakterističnih manifestnih pojava i oblika reagiranja i ponašanja, kroz koje ovaj razvoj prolazi:

a) Imitacija: Uočljiva i dominantna osobenost socijalnog razvoja $\mathrm{u}$ predškolskoj dobi, a ujedno i dominantan oblik socijalnog učenja kod djeteta, je imitacija. Prema istraživanjima Hagmana i Dunbera (prema Hwang P., Nilsson B., 2000.) dijete imitira ponašanje koje vidi kod odraslih. Nađena je visoka povezanost između strahova kod djece i njihovih majki, što ukazuje da djeca često nauče da se plaše situacija promatrajući kako majka reagira $u$ takvim situacijama.(Pehar-Zvačko L., 2000. str. 33.)

b) Negativizam: Najtipičniji i najčešći oblik ispoljavanja negativizma ogleda se u reagiranju djeteta koje je, po pravilu, drukčije od onog koje se od njega očekuje, čime dijete pruža otpor zahtjevima drugih i tako zadovoljava svoju potrebu samopotvrđivanja. U drugim vidovima negativizam se može manifestirati kroz samo djelimično izvršavanje postavljenih zahtjeva, ili da dijete na postavljene zahtjeve reagira potpunim zaustavljanjem aktivnosti, dakle, uopće ne reagira.

c) Ovaj oblik ponašanja se kod djece javlja oko treće godine, dostiže najveću frekvenciju do pete godine, a nakon toga naglo pada.

d) Svađa: Svađa je uobičajena i česta forma socijalnog ponašanja djeteta, naročito djeteta mlađe predškolske dobi, a manifestira se otimanjem igračaka u igrama u grupi, vikanjem, vrištanjem, plačem, a ponekad i fizičkim konfrontiranjem sa drugim djetetom.

e) Agresivnost: Dijete svoju agresivnost može ispoljavati prema stvarima i predmetima, prema drugim osobama, ali i prema samom sebi. Potrebno je razlikovati uobičajene, «normalne» oblike 
agresivnih reakcija kod djece koji se javljaju tokom razvoja, od reakcija koje odstupaju od onih koje su na tom stupnju uobičajene ili predugo traju sa porastom u intenzitetu i učestalosti. Česte su predrasude da se kažnjavanjem mogu postići korisni efekti, jer se ova forma socijalnog ponašanja djeteta najčešće javlja kao dječja reakcija na frustraciju, pa se kažnjavanjem produžava i još pogoršava osujećenost $i$ spriječenost djeteta $u$ zadovoljenju njegovih potreba koje odrasli nisu prepoznali.

f) Rivalstvo: Ova forma socijalnog ponašanja djeteta uglavnom se manifestira u igri, kada dijete, na račun druge djece u igri, želi pokazati svoju superiornost. Ono će, npr., drugom djetetu oteti igračku, ne zato što je želi, već da pokaže svoju nadmoć, kojom smatra da će privući pažnju i zadobiti ljubav i naklonost odraslih, ako mu je potreba za tim nezadovoljena.

g) Dominantno ponašanje: Ovaj oblik ponašanja ima sličnosti sa rivalstvom, ali kod ispoljavanja dominantnosti dijete, ne samo da želi pokazati svoju superiornost prema drugoj djeci, već se drugoj djeci ili odraslima želi nametnuti, imati odlučujući utjecaj na njih, pridobiti njihovu punu pažnju.

h) Egocentrizam: Posebno rani period u razvoju predškolskog djeteta karakteriše dječje shvatanje da ono misli i postupa kao i svi drugi koji ga okružuju i da to što ono misli, osjeća ili radi trebaju tako činiti i drugi. Ovo otežava njegovu suradnju sa drugom djecom i odraslima, pa dijete, kroz socijalnu interakciju, kroz proces sazrijevanja i učenja, postepeno napušta ovakvo gledište i tako prevladava i napušta svoj egocentrizam.

i) Kooperativnost: Uspostavljanje suradnje sa drugima $\mathrm{u}$ toku socijalnog razvoja predškolskog djeteta ima različite razvojne forme manifestiranja. Obično do šeste godine ne uočava se neka značajnija spremnost djeteta za zajednički rad i suradnju sa drugima, ali se može uočiti spremnost za odobravanje koju dijete ispoljava u ponašanju kada želi da bude zapaženo i u centru pažnje.

j) Simpatija: Djeca vrlo rano pokazuju nastojanje i spremnost da pruže pomoć drugima, da ih utješe, grle, maze, ljube i sl. Ova forma ranog ponašanja vrlo je značajna za normalan socijalni razvoj djeteta $\mathrm{i}$ razvoj njegove ličnosti. 
Formiranje svijesti o sebi je značajan segment socijalnog razvoja djeteta predškolske dobi i razvija se postupno tokom prve dvije godine, nakon čega je dijete u stanju shvatiti relaciju lično - društveno, moje - tuđe i sl. Ovaj razvoj se ostvaruje kroz socijalnu interakciju djeteta i njegove okoline, ali je on istovremeno i preduvjet uspješne interakcije, jer dijete koje ima realnu sliku o sebi samom, koje ima razvijeno poimanje sebe, lakše i uspješnije ostvaruje socijalnu interakciju. Socijalni razvoj predškolskog djeteta na relaciji lično - društveno, uporedo sa kronološkim uzrastom ima sljedeće karakteristične manifestne oblike (prema: LAP-ljestvica - Learning Accomplishment Profile - Profil napredovanja u učenju, Chapel Hill Training Outreach Project, 1998.):

Tabela 4.: Socijalni razvoj djeteta u segmentu lično - društveno (prema Learning Accomplishment Profil-LAP)

\begin{tabular}{|c|c|}
\hline $\begin{array}{c}\text { Dob } \\
\text { (u } \\
\text { mjes.) }\end{array}$ & Karakteristične manifestacije socijalnog ponašanja \\
\hline $\mathbf{1 2}$ & Daje odraslom igračku na zahtjev \\
\hline $\mathbf{1 6}$ & Imitira kućne aktivnosti \\
\hline $\mathbf{1 8}$ & Vuče drugu osobu da joj nešto pokaže \\
\hline $\mathbf{2 1}$ & Imitira svoje igre \\
\hline $\mathbf{2 4}$ & Govori puno ime \\
\hline $\mathbf{3 0}$ & $\begin{array}{c}\text { Odgovara na poziv. Sjeda u krug i pridružuje se grupi u } \\
\text { imitiranju vođe. }\end{array}$ \\
\hline $\mathbf{3 6}$ & $\begin{array}{c}\text { Igra se jednostavnih grupnih igara. Sklanja igračke uz nadzor. } \\
\text { Dijeli igračke sa drugima. Preuzima svoj red. Sluša priče } \\
\text { «pažljivo». Ispoljava nezadovoljstvo verbalno radije nego } \\
\text { fizički. Zna reći koji je spol. }\end{array}$ \\
\hline $\mathbf{4 2}$ & $\begin{array}{c}\text { Odvaja se lahko od roditelja. Pokazuje sebe na grupnoj } \\
\text { fotografiji. Izvodi nešto za druge. Igra se drugom djecom. Pita } \\
\text { za dozvolu da koristi stvari koje pripadaju drugima. }\end{array}$ \\
\hline $\mathbf{4 8}$ & $\begin{array}{c}\text { Sklanja igračke bez nadzora. Igra se i surađuje s drugom } \\
\text { djecom. Učestvuje u dramskoj igri. Kaže «hvala» za uslugu ili } \\
\text { kompliment. Kaže «molim vas» kad nešto traži. Odlazi da } \\
\text { prenese neku poruku ili nešto uredi izvan prostorije. Kaže } \\
\text { koliko mu je godina. Kaže ime brata ili sestre. Kaže ime uluce i } \\
\text { broj. }\end{array}$ \\
\hline $\mathbf{5 4}$ & $\begin{array}{c}\text { Traži pažnju za svoju izvedbu. Kaže «oprostite» kada ometa ili } \\
\text { prekida druge }\end{array}$ \\
\hline
\end{tabular}




\begin{tabular}{|c|c|}
\hline $\mathbf{6 0}$ & $\begin{array}{c}\text { Bira svoje prijatelje. Igra takmičarske sportske igre. Imenuje } \\
\text { dvije emocije. Kaže da mu je rođendan. }\end{array}$ \\
\hline $\mathbf{6 6}$ & $\begin{array}{c}\text { Pomaže odraslima u jednostavnim zadacima. Igra jednostavne } \\
\text { takmičarske stone igre. }\end{array}$ \\
\hline $\mathbf{7 2}$ & $\begin{array}{c}\text { Kaže kompletnu adresu. Radi u maloj grupi. Pleše u grupi ples } \\
\text { sa ponavljanjem. }\end{array}$ \\
\hline
\end{tabular}

U praćenju razvoja djeteta predškolske dobi koristi se i pristup utvrđivanja normi na osnovu centila. Centilna vrijednost nekog rezultata mjerenja određuje položaj tog rezultata u populaciji (Tabele 5 . i 6.).

Tabela 5 .: Centilne vrijednosti za visinu djece predškolske dobi (Furlan, I. 1991)

\begin{tabular}{|c|c|c|c|c|c|c|c|}
\hline \multirow{2}{*}{$\begin{array}{c}\text { Dob } \\
\text { (god.) }\end{array}$} & \multicolumn{7}{|c|}{ Centilna vrijednost (dječaci / djevojčice) } \\
\hline 2,5 & $87 / 85$ & $88 / 86$ & $90 / 90$ & $92 / 91$ & $94 / 94$ & $97 / 97$ & $99 / 98$ \\
\hline 3 & $91 / 89$ & $92 / 90$ & $94 / 93$ & $97 / 96$ & $98 / 98$ & $100 / 101$ & $102 / 103$ \\
\hline 3,5 & $93 / 93$ & $96 / 94$ & $98 / 96$ & $100 / 100$ & $102 / 102$ & $104 / 105$ & $106 / 107$ \\
\hline 4 & $97 / 96$ & $99 / 98$ & $101 / 100$ & $104 / 102$ & $107 / 105$ & $109 / 109$ & $110 / 111$ \\
\hline 4,5 & $99 / 99$ & $102 / 101$ & $104 / 104$ & $107 / 107$ & $110 / 109$ & $112 / 114$ & $113 / 115$ \\
\hline 5 & $102 / 103$ & $105 / 104$ & $107 / 107$ & $110 / 109$ & $113 / 112$ & $116 / 116$ & $117 / 118$ \\
\hline 5,5 & $104 / 106$ & $108 / 108$ & $111 / 110$ & $114 / 113$ & $117 / 116$ & $120 / 119$ & $121 / 121$ \\
\hline 6 & $110 / 107$ & $112 / 110$ & $115 / 114$ & $118 / 117$ & $121 / 121$ & $125 / 125$ & $128 / 127$ \\
\hline
\end{tabular}

Tabela 6 .: Centilne vrijednosti za težinu djece predškolske dobi (Furlan, I. 1991)

\begin{tabular}{|c|c|c|c|c|c|c|c|}
\hline \multirow{2}{*}{$\begin{array}{c}\text { Dob } \\
\text { (god.) }\end{array}$} & 5 & 10 & 25 & 50 & 75 & 90 & 95 \\
\hline 2,5 & $11,6 / 10,8$ & $12,0 / 11,6$ & $12,9 / 12,5$ & $13,6 / 13,4$ & $14,6 / 14,5$ & $15,6 / 16,1$ & $16,5 / 17,3$ \\
\hline 3 & $12,3 / 11,7$ & $13,0 / 12,5$ & $13,7 / 13,4$ & $14,6 / 14,4$ & $15,6 / 15,6$ & $16,7 / 17,0$ & $17,6 / 18,7$ \\
\hline 3,5 & $13,0 / 12,6$ & $13,0 / 13,4$ & $14,6 / 14,3$ & $15,5 / 15,4$ & $17,7 / 16,8$ & $17,7 / 18,4$ & $18,5 / 20,3$ \\
\hline 4 & $13,7 / 13,4$ & $14,5 / 14,2$ & $15,4 / 15,2$ & $16,6 / 16,4$ & $17,7 / 17,9$ & $18,8 / 19,7$ & $19,7 / 21,7$ \\
\hline 4,5 & $14,3 / 14,1$ & $15,2 / 15,0$ & $16,3 / 16,0$ & $17,5 / 17,4$ & $18,8 / 19,0$ & $20,0 / 21,2$ & $21,3 / 22,9$ \\
\hline 5 & $15,6 / 15,1$ & $16,3 / 16,1$ & $17,5 / 17,2$ & $18,8 / 18,6$ & $20,5 / 20,2$ & $21,9 / 22,1$ & $23,2 / 23,5$ \\
\hline 5,5 & $16,5 / 16,0$ & $17,6 / 17,2$ & $19,0 / 18,5$ & $20,6 / 20,0$ & $22,3 / 21,4$ & $24,0 / 23,2$ & $25,4 / 25,1$ \\
\hline 6 & $17,4 / 16,1$ & $18,1 / 17,5$ & $19,6 / 19,0$ & $21,5 / 21,1$ & $23,4 / 22,7$ & $25,9 / 24,9$ & $27,9 / 26,5$ \\
\hline
\end{tabular}

Ako npr., tjelesna visina djeteta ima vrijednost od 92 centila, to pokazuje da od stotinu djece u populaciji tog uzrasta 91 dijete ima nižu, a osmero djece višu vrijednost na toj osobini koja je mjerena. Ili, ako djevojčica od 5 godina ima tjelesnu težinu 17,5 kilograma, iz centilnih vrijednosti se može očitati da ta vrijednost odgovara centilnoj 
vrijednosti nešto većoj od 25 , ali znatno manjoj od 50 centila, dakle, više od $50 \%$ njenih vršnjakinja ima veću, a samo nešto više od $25 \%$ njih manju tjelesnu težinu. Svakako da pri ovakvim ocjenama treba uzeti u obzir i uticaj određenih konstitucijskih nasljednih faktora, ali bi ovakav podatak zahtijevao dalju analizu mogućih uzroka: da li je u pitanju neki endokrini poremećaj, bolest ili eventualna pothranjenost, kako bi se preventivno i pravovremeno moglo djelovati.

$\mathrm{Na}$ osnovu praćenja i mjerenja na reprezentativnom uzorku centilne norme se mogu uraditi i za druga područja ili aspekte razvoja: za motorički razvoj, razvoj govora, socio-emocionalni razvoj i dr.

\section{Zaključak}

Psihofizički razvoj ljudske jedinke u predškolskoj dobi je najkompleksniji i najdinamičniji razvoj u odnosu na druge periode razvoja tokom života. Taj razvoj kod ljudske vrste, za razliku od razvoja kod drugih živih organizama je specifičan po mnogo obilježja, on nije linearan, već diskontinuiran, skokovit i na mahove. U tom razvoju su utvrđene određene karakteristike i zakonitosti koje omogućuju njegovo praćenje i pravovremeno utvrđivanje eventualnih odstupanja ili zastoja. Poznavanje osobenosti i praćenje toka razvoja u ovom izuzetno značajnom periodu ima veliku preventivnu važnost i funkciju, jer svako zaostajanje, usporavanje ili smetnje u normalnom razvoju stvaraju krupne posljedice u daljem razvoju. Na osnovu temeljitih naučnih saznanja utvrđene su brojne norme po kojima se može pratiti tok razvoja u ovom razvojnom periodu. Norme su, naravno, samo orijentacioni pokazatelji, a uvijek treba imati na umu osobenost razvoja u ovom periodu i uvažavati izražene individualne razlike.

\section{LITERATURA:}

1. Bergant M. (1974.) Teme iz pedagoške sociologije. Zagreb: Školska knjiga

2. Capone C. (1977.) Majka i dete, Beograd: Naučna knjiga

3. Čolanović - Smiljanić, V. (1968.) Dječja psihologija, Sarajevo: Svjetlost

4. Furlan, I. (1991.) Čovjekov psihički razvoj. Zagreb: ‘̌kolska knjiga 
5. Hwang, P., Nilson, B. (2000.) Razvojna psihologija-od fetusa do odraslog. Zenica: Dom štampe

6. Kamenov E. (2002.) Predškolska pedagogija. Beograd: Zavod za udžbenike i nastavna sredstva

7. Kendić, S. et all (2005.) Zdravstvena i psihosocijalna zaštita malog $i$ predškolskog djeteta. Bihać: Pedagoški fakultet

8. Laplanche J., Pontalis J.B. (1992.) Rječnik psihoanalize. Zagreb: August Cesarec.

9. ------- LAP-ljestvica (Learning Accomplishment Profile - Profil napredovanja u učenju, Chapel Hill Training Outreach Project, 1998.):

10. Mitrović D. (1986.) Predškolska pedagogija. Sarajevo: Svjetlost

11. Pašalić-Kreso, A. (2004.) Koordinate obiteljskog odgoja. Sarajevo: Jež

12. Pehar-Zvačko L. (2002.) Razvojni problemi djece. Sarajevo: Filozofski fakultet

13. Petz B. et. al. (1992.) Psihologijski rječnik. Zagreb: Prosvjeta

14. Rošić F. (2003.) Kako pomoći djetetu koje se boji, Zenica: Dom štampe

15. Štarc, B.et all. (2022.) Osobine i psihološki uvjeti razvoja djeteta predškolske dobi. Zagreb: Tehnička knjiga

16. Valon A. (1999.) Psihički razvoj deteta. Beograd: Zavod za udžbenike i nastavna sredstva

17. Ross, V., Marshall, M. H., Scott, A. M. (1998.) Dječja psihologijamoderna znanost. Jastrebarsko: Naklada Slap

18. Vodak P., Šulc A.(1966.) Mane i poremećaji ponašanja u dječijem dobu, Sarajevo: Zavod za proučavanje školskih i prosvjetnih pitanja 


\author{
Fehim Rošić, PhD \\ University of Bihac \\ Pedagogical Faculty \\ fehim.rosic@gmail.com
}

Original scientific article

\title{
TRACKING THE EARLY GROWTH AND DEVELOPMENT OF PRESCHOOL CHILD-CHARACTERISTICS AND STANDARDS DEVELOPMENT
}

\section{Abstract}

The period of the earliest development of the human individual is the most intense and the most dynamic period of development and is extremely important in the overall process of human growth and development. Development in this period is, for many characteristics, different from development in the coming periods. Although the process of the development of a unique and integral, it can be traced, to study and analyze per separate areas, physical, cognitive, socio-emotional, or language development. On the basis of the substantiated scientific achievements found certain standards that, like the orientation indicators, help in monitoring the flow of this development. Knowledge of the characteristics of the development of the pre-school and its monitoring has a special preventive significance from the point of view of the timely recognition of interference, lag, or disorders in the developing world, but also the importance of the educational practice in the sense of providing the optimal conditions for the growth and development of the child.

Keywords: development, the legality of early development, standards, LAPnorms, standards percentile 


$$
\begin{aligned}
& \text { الأستاذ الدكتور فهيم روشيتش } \\
& \text { جامعة بيهاتش } \\
& \text { كلية التربية }
\end{aligned}
$$

fehim.rosic@gmail.com

\section{متابعة النشأة والنمو المبكريْن لدى الأولاد في سن قبل المدرسة

$$
\text { - الخصائص ومعايير النمو }
$$

\section{الخلاصة}

فترة النمو في مراحلها الأولى للفرد البشري هي أقوى فترات النمو وأكثرها حيوية ولها

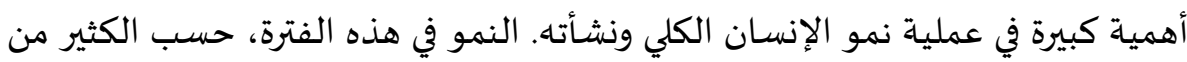

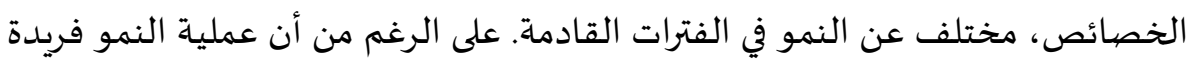

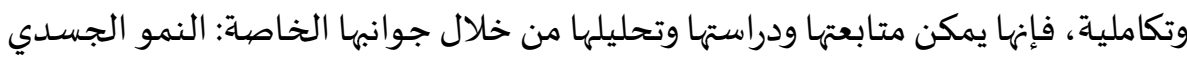

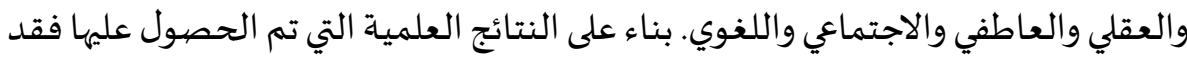

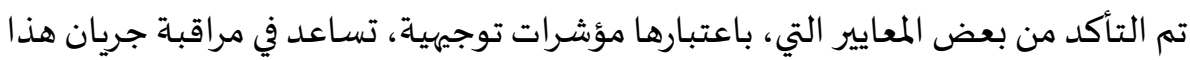

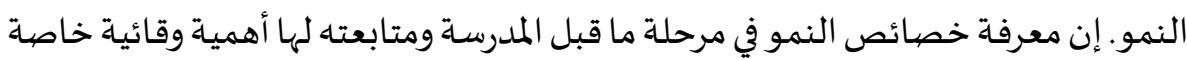

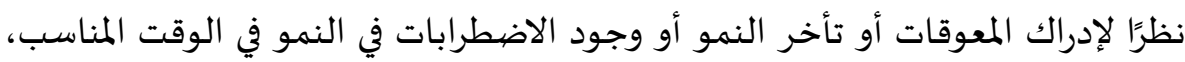

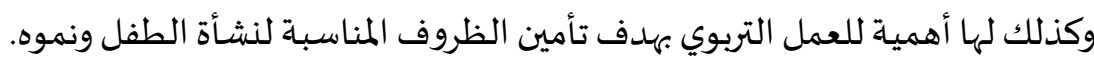
الكلمات الرئيسة: النمو، قوانين النمو المبكر، المعايير، معايير LAP، المعائ المعايير المئوية 